\title{
Source, composition, and environmental implication of neutral carbohydrates in sediment cores of subtropical reservoirs, South China
}

\author{
Dandan Duan ${ }^{1,2}$, Dainan Zhang ${ }^{1,2}$, Yu Yang ${ }^{1}$, Jingfu Wang ${ }^{3}$, Jing'an Chen ${ }^{3}$, and Yong Ran ${ }^{1}$ \\ ${ }^{1}$ State Key Laboratory of Organic Geochemistry, Guangzhou Institute of Geochemistry, Chinese Academy of Sciences, \\ Guangzhou, Guangdong 510640, China \\ ${ }^{2}$ University of Chinese Academy of Sciences, Beijing 100049, China \\ ${ }^{3}$ State Key Laboratory of Environmental Geochemistry, Institute of Geochemistry, Chinese Academy of Sciences, \\ Guiyang 55002, China
}

Correspondence to: Yong Ran (yran@gig.ac.cn)

Received: 23 November 2016 - Discussion started: 29 November 2016

Revised: 9 July 2017 - Accepted: 7 August 2017 - Published: 15 September 2017

\begin{abstract}
Neutral monosaccharides, algal organic matter (AOM), and carbon stable isotope ratios in three sediment cores of various trophic reservoirs in South China were determined by high-performance anion-exchange chromatography, Rock-Eval pyrolysis, and Finnigan Delta Plus XL mass spectrometry, respectively. The carbon isotopic compositions were corrected for the Suess effect. The concentrations of total neutral carbohydrates (TCHO) range from 0.51 to $6.4 \mathrm{mg} \mathrm{g}^{-1}$ at mesotrophic reservoirs, and from 0.83 to $2.56 \mathrm{mg} \mathrm{g}^{-1}$ at an oligotrophic reservoir. Monosaccharide compositions and diagnostic parameters indicate a predominant contribution of phytoplankton in each of the three cores, which is consistent with the results inferred from the corrected carbon isotopic data and $\mathrm{C} / \mathrm{N}$ ratios. The sedimentary neutral carbohydrates are likely to be structural polysaccharides and/or preserved in sediment minerals, which are resistant to degradation in the sediments. Moreover, the monosaccharide contents are highly related to the carbon isotopic data, algal productivity estimated from the hydrogen index, and increasing mean air temperature during the past 60 years. The nutrient input, however, is not a key factor affecting the primary productivity in the three reservoirs. The above evidence demonstrates that some of the resistant monosaccharides have been significantly elevated by climate change, even in low-latitude regions.
\end{abstract}

\section{Introduction}

Carbohydrates are the most abundant compounds in the biosphere, and are present in the natural environment as both structural and storage compounds of aquatic and terrestrial organisms. They comprise about $20-40 \mathrm{wt} \%$ of plankton (Parsons et al., 1984), more than $40 \mathrm{wt} \%$ of bacteria (Moers et al., 1993), and more than $75 \mathrm{wt} \%$ of vascular plants (Moers et al., 1993). Due to their high biological reactivity and availability, carbohydrates are preferentially utilized by heterotrophic organisms (e.g., bacteria and fungi) in water columns (Hernes et al., 1996; Khodse et al., 2007), leading to the preservation of some refractory structural carbohydrates in sediments (Cowie and Hedges, 1994; Burdige et al., 2000; Jensen et al., 2005; He et al., 2010). Moreover, the compositional signature of structural carbohydrates depends more on planktonic sources than the diagenetic pathway (Hernes et al., 1996). Some structural fractions could be used for elucidating sources, deposition processes, and diagenetic fates of organic matter (OM) in aquatic environments (Cowie and Hedges, 1984; Moers et al., 1990; Hicks et al., 1994; Meyers, 1997; Unger et al., 2005; Aufdenkampe et al., 2007; Skoog et al., 2008; Khodse and Bhosle, 2012; Panagiotopoulos et al., 2012).

Carbon isotope analyses in sedimentary OM offer another important tool for reconstructing the history of nutrient loading and eutrophication in lacustrine sediments (Schelske and Hodell, 1991, 1995). Phytoplankton preferentially re- 
move dissolved ${ }^{12} \mathrm{CO}_{2}$ from epilimnetic water and deplete ${ }^{12} \mathrm{C}$ in the remaining dissolved inorganic carbon (Hodell and Schelske, 1998). As supplies of ${ }^{12} \mathrm{CO}_{2}$ become diminished, phytoplankton discriminate less against ${ }^{13} \mathrm{C}$ and sinking $\mathrm{OM}$, incorporating more ${ }^{13} \mathrm{CO}_{2}$. Therefore, increased or decreased productivity can be reflected by enriched or depleted values of $\delta^{13} \mathrm{C}$ in $\mathrm{OM}$ from the underlying sediments. However, during recent years, the $\delta^{13} \mathrm{C}$ values in atmospheric $\mathrm{CO}_{2}$, water column, and sedimentary OM have been significantly diminished by the Suess effect (Schelske and Hodell, 1995), which is defined as the change in the abundance of carbon isotopes $\left({ }^{14} \mathrm{C},{ }^{13} \mathrm{C},{ }^{12} \mathrm{C}\right)$ in natural $\mathrm{OM}$ reservoirs due to anthropogenic activities (e.g., fossil fuel combustion) (Keeling, 1979). Thus, the Suess effect needs to be considered when applying $\delta^{13} \mathrm{C}$ in lacustrine sediments as a proxy for aquatic productivity. Although O'Reilly et al. (2005) had not corrected for the Suess effect in the heterotrophic Lake Tanganyika in Africa, Verburg (2007) found that the corrected $\delta^{13} \mathrm{C}$ values were used as a productivity proxy. In the Pearl River Delta (PRD), the development of industrialization and urbanization could enhance the high emission of $\mathrm{CO}_{2}$ during recent years. Hence, the $\delta^{13} \mathrm{C}$ values of reservoir sediments in the PRD need to be corrected for the Suess effect.

Several studies have shown that climate warming plays a significant role in algal productivity by using the $\mathrm{S} 2$ proxy in the Arctic lakes during recent decades (Outridge et al., 2005, 2007; Stern et al., 2009; Carrie et al., 2010). However, Kirk et al. (2011) investigated 14 Canadian Arctic and subArctic lakes and found that the relationship between the S2 proxy and climate warming was irrelevant. In addition, only limited investigations have focused on the impact of global change on aquatic productivity in subtropical lakes (Hambright et al., 1994; Smol et al., 2005). Therefore, the above observations call for more investigations on the effects of trophic levels, early diagenesis, and sources of organic matter on the relationship between algal productivity and climate warming.

For this investigation, subtropical reservoirs in rural areas with different trophic states were chosen. Our purpose is to assess the source and diagenetic state of the carbohydrates, and their relationship with algal productivity in sediment cores by using carbohydrate compositions combined with Rock-Eval parameters, carbon isotopic composition, and elemental $\mathrm{C} / \mathrm{N}$ ratios. In addition, trace metal data $(\mathrm{Cu}$ and $\mathrm{Zn})$ cited from our previous paper (Duan et al., 2014) are used to help in understanding the source of carbohydrates. Moreover, neutral carbohydrates and recorded temperature data were statistically analyzed to explore the effects of climate warming on the historical variations of neutral carbohydrates in subtropical regions over the last 6 decades.

\section{Materials and methods}

\subsection{Study area and sample collection}

Zengtang reservoir (ZT), Lian'an reservoir (LA), and Xinfengjiang reservoir (XFJ) with different depths and trophic states were chosen for this investigation. The reservoirs are mainly supplied by rainfall and are far away from the industrial center. Aquaculture and dredging activities are forbidden in the investigated reservoirs. Detailed descriptions of the study sites are shown in the previous literature (Duan et al., 2015). In brief, ZT is a shallow, polymictic reservoir with a mesotrophic level, whereas LA is a deep and mesotrophic reservoir. XFJ is a deep and oligotrophic reservoir. Both $\mathrm{LA}$ and $\mathrm{XFJ}$ are monomictic reservoirs. The most abundant algal species in the ZT, LA, and XFJ reservoirs are green algae, cyanophyta, and diatoms.

Undisturbed sediment cores were collected from the central part of the studied lakes using a $6 \mathrm{~cm}$ diameter gravity corer with a Plexiglass liner in 2010 and 2011. The water depths for the sampling sites at the ZT, LA, and XFJ reservoirs are 3,17 , and $36 \mathrm{~m}$, respectively. The core liners were put down slowly in order to avoid disturbance. The sediment cores were sliced into $2 \mathrm{~cm}$ thick intervals using extrusion equipment. It is noted that the top four slices of the ZT core were merged into two intervals $(0-4$ and $5-8 \mathrm{~cm})$ due to the insufficient amount of samples for neutral sugar analysis. All subsamples were immediately placed in plastic bags, sealed, and stored at a low temperature $\left(0-10^{\circ} \mathrm{C}\right)$, and then were quickly transported to the laboratory, where they were freezedried and stored until further analysis.

\subsection{Physicochemical properties in water}

Vertical and temporal variation of chlorophyll $a$, dissolved oxygen, and temperature in the water column of the LA reservoir were recorded by a CTD-90M probe (Sea \& Sun Technology, Germany) in increment mode, which enables us to carry out a great number of profile records in the field (Fig. S1 in the Supplement). For the XFJ reservoir, the physicochemical record was conducted only in March 2014. The lack of data from the ZT reservoir is due to its reconstruction after the sediment core sampling.

\subsection{Rate of sedimentation}

Each sliced sample was analyzed for ${ }^{210} \mathrm{~Pb}$ and ${ }^{137} \mathrm{Cs}$ radiometric dating (Duan et al., 2015). Briefly, the activities of ${ }^{210} \mathrm{~Pb}$ and ${ }^{137} \mathrm{Cs}$ were measured by a S-100 Multi Channel Spectrometer (Canberra, USA) with a PIPS Si detector and a GCW3022 H-P Ge coaxial detector, respectively. Excess ${ }^{210} \mathrm{~Pb}$ activities were measured by subtracting the average ${ }^{210} \mathrm{~Pb}$ activities of deeper layers in sediment cores and the constant rates of supply dating models (CRS) were used for the calculation of chronology and sedimentation rates. 


\subsection{Rock-Eval analysis}

All of the samples were analyzed by Rock-Eval 6 (Vinci Technologies, France). The detailed procedures were reported in the previous literature (Duan et al., 2014, 2015). Briefly, bulk sediment was firstly pyrolyzed in an inert, $\mathrm{O}_{2}$ free oven $\left(100-650^{\circ} \mathrm{C}\right)$ and secondly combusted in an oxidation oven $\left(400-850^{\circ} \mathrm{C}\right)$. Several parameters such as $\mathrm{S} 1$, S2, S3, residue carbon (RC) and total organic carbon (TOC) can be generated by a flame ionization detector (FID) and infrared spectroscopy (IR). S1 and S2 represent the fractions of hydrocarbons (HCs) released during the pyrolysis step, where $\mathrm{S} 3$ was derived from the fractions of $\mathrm{CO}$ and $\mathrm{CO}_{2}$ released during the two procedures. The residue carbon after combustion defined as RC and the sum of the generated organic fractions is TOC. The hydrogen index (HI) and oxygen index (OI) are calculated by normalizing the contents of S2 and $\mathrm{S} 3$ to TOC.

\subsection{Stable carbon isotopic analysis}

Samples were initially decarbonated by the moderate $\mathrm{HCl}$ solution, and then the stable carbon isotopic composition was measured by Finnigan Delta Plus XL mass spectrometry. The $\delta^{13} \mathrm{C}$ values (\%o) were given by the equation below:

$\delta^{13} \mathrm{C}(\% \circ)=\left(R_{\text {sample }} / R_{\text {standard }}-1\right) \times 1000$,

where $R$ is the ${ }^{13} \mathrm{C} /{ }^{12} \mathrm{C}$ ratio and the standard is V-Pee Dee Belemnite. Black carbon (product ID GBW04408, National Research Center for Certified Reference Materials, China) was used as the reference standard for the determination of accuracy and precision. The precision of $\delta^{13} \mathrm{C}$ for the replicates was $<0.19 \% \circ \pm 0.12(n=40)$.

Measured values of $\delta^{13} \mathrm{C}$ were corrected for the Suess effect with the following polynomial equation (Schelske and Hodell, 1995), where $t$ is time (in years):

$$
\begin{aligned}
\delta^{13} \mathrm{C}(\% \circ)= & -4577.8+7.3430 t-3.9213 \times 10^{-3} t^{2} \\
& +6.9812 \times 10^{-7} t^{3} .
\end{aligned}
$$

The calculated time-dependent depletion in $\delta^{13} \mathrm{C}$ induced by fossil fuel combustion since 1840 was subtracted from the measured $\delta^{13} \mathrm{C}$ for each dated sediment section.

\subsection{Neutral sugar analysis}

Sediment samples (about $5 \mathrm{mg}$ ) from the three reservoirs were weighted and hydrolyzed in glass ampules with $12 \mathrm{M}$ $\mathrm{H}_{2} \mathrm{SO}_{4}$ for $2 \mathrm{~h}$ at room temperature. After $9 \mathrm{~mL}$ of Milli-UV + water were added $\left(1.2 \mathrm{M} \mathrm{H}_{2} \mathrm{SO}_{4}\right.$, final concentration of acid), the ampules were flame-sealed and the samples were stirred and hydrolyzed in a $100^{\circ} \mathrm{C}$ water bath for $3 \mathrm{~h}$. The hydrolysis was terminated by placing the ampules in an ice bath for $5 \mathrm{~min}$. Then, the deoxyribose was added as the internal standard (Philben et al., 2015). Before instrumental analysis, the samples were run through a mixed bed of anion (AG 2-X8, 20-50 meshes, Bio-Rad) and cation (AG 50WX8, 100-200 meshes, Bio-Rad) exchange resins (Philben et al., 2015). Self-absorbed AG11 A8 resin was utilized to remove the acid. The volume of resin needed for complete neutralization depended on the amount of acid used for hydrolysis (Philben et al., 2015). After purification with a mixture of cation and anion exchange resins, neutral sugars were isocratically separated with $25 \mathrm{mM} \mathrm{NaOH}$ on a PA 1 column in a Dionex 500 ion chromatography system, which was equipped with a pulsed amperometric detector (PAD, model ED40) (Philben et al., 2015). The detector setting was based on Skoog and Benner (1997). Chromatographic data were recorded with a personal computer equipped with Hewlett Packard Chemstation software (Skoog and Benner, 1997; Kaiser and Benner, 2000).

For every 10 analyses, a blank sample and a duplicate sample were analyzed to check accuracy and precision. No neutral sugars were detected in the blanks. Only glucose, galactose, mannose, rhamnose, fucose, and xylose were detected and analyzed in samples due to the loss of ribose in the process of acid hydrolysis. The recovery of the monosaccharides in the sediments ranged from 73 to $95 \%$. The analytical precision of duplicate samples performed on different days was within $\pm 3 \%$ for glucose and $\pm 5 \%$ for other sugars. In this study, the total neutral carbohydrates (TCHO) are defined as the sum of all identified monosaccharides.

\section{Results}

\subsection{Physicochemical properties of water}

As shown in Fig. S1, chlorophyll $a$ concentrations in the water column of LA are higher in spring and summer than in fall and winter, which is consistent with the seasonal distribution of the contents of dissolved oxygen. The vertical profiles of chlorophyll $a$ and dissolved oxygen also show similar patterns; depleted dissolved oxygen in the hypolimnion accompanies a low content of chlorophyll $a$ throughout the year, suggesting the productivity significantly contributes to dissolved oxygen contents. In general, the bottom sediments in LA are mostly under anaerobic conditions. Water temperature is higher in summer and fall, resulting in thermal stratification in the water column. During winter, the lake mixes from top to bottom due to the decrease in temperature (socalled autumn overturn). Therefore, the relatively high contents of nutrients can be transported by the water flow to the upper depths, resulting in the increase in nutrients and productivity in the entire water column.

The concentration of chlorophyll $a$ (average: $0.94 \mu \mathrm{g} \mathrm{L}-1$ ) in the water column of XFJ is much lower than that in LA. The oxygen contents vary from $9 \mathrm{mgL}^{-1}$ at a depth of $1 \mathrm{~m}$ to $8.54 \mathrm{mg} \mathrm{L}^{-1}$ at a depth of $36 \mathrm{~m}$ (Fig. S1), suggesting the bottom sediments are under aerobic conditions. 

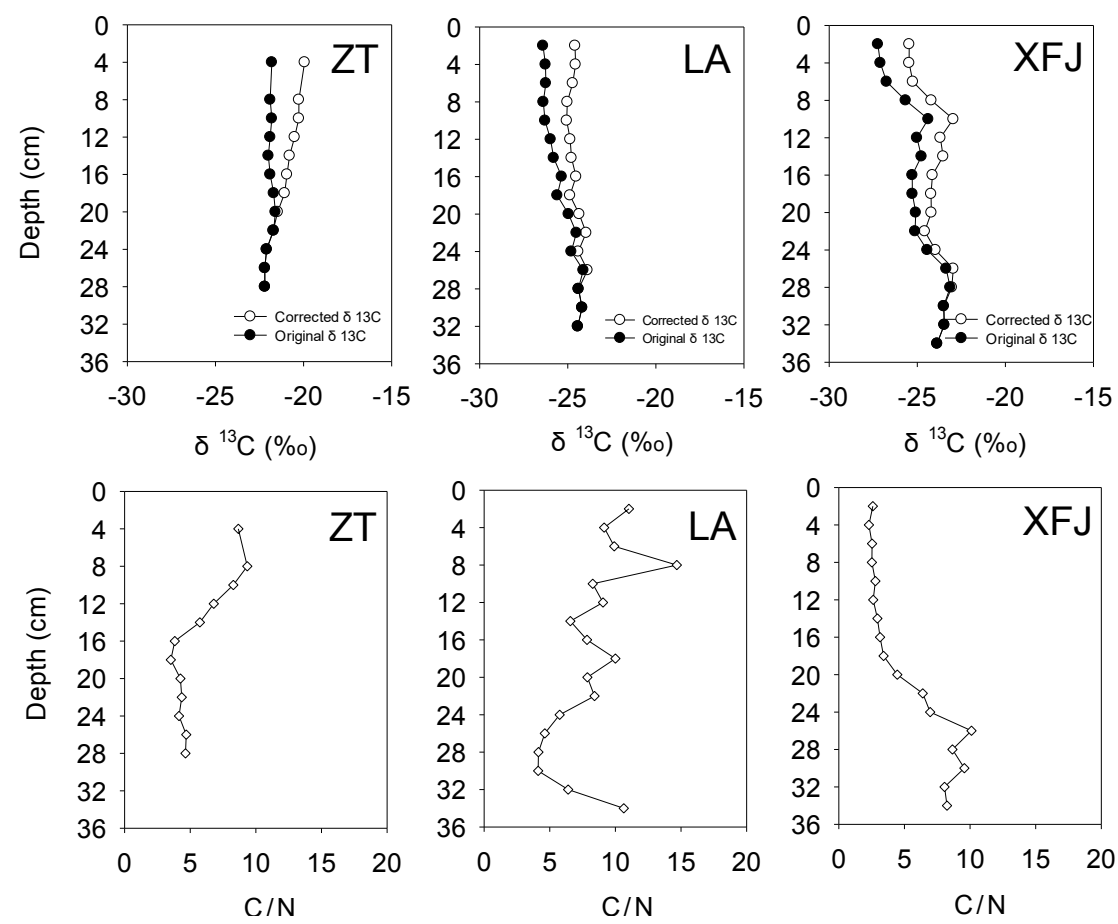

Figure 1. Vertical variations of original $\delta^{13} \mathrm{C}$, corrected $\delta^{13} \mathrm{C}$, and $\mathrm{C} / \mathrm{N}$ in sediment cores of three reservoirs.

\subsection{Characteristics of $\mathrm{OM}$}

The data from Rock-Eval pyrolysis are listed in Table S1 in the Supplement, which were reported previously (Duan et al., 2015). As shown in Table S1, pyrolytic parameters S1 and S2 represent the fractions of HCs released during the pyrolysis step, where $\mathrm{S} 3$ was derived from the fractions of $\mathrm{CO}$ and $\mathrm{CO}_{2}$ released during the pyrolysis and oxidation procedures. The HI is calculated by normalizing the contents of $\mathrm{S} 2$ to TOC (Duan et al., 2015). TOC and HI are in the ranges of 0.78-2.98 and 114-231 $\mathrm{mg} \mathrm{HC} \mathrm{g}^{-1} \mathrm{TOC}$, respectively, in the ZT core; in the ranges of $0.88-4.31$ and $151-229 \mathrm{mg} \mathrm{HC} \mathrm{g}^{-1}$ TOC, respectively, in the LA core; and in the ranges of $0.47-$ 1.76 and $141-196 \mathrm{mg} \mathrm{HC} \mathrm{g}^{-1} \mathrm{TOC}$, respectively, in the XFJ core. In general, the HI values are enriched in the surface layers of all the sediment cores.

$\delta^{13} \mathrm{C}$ values (\%o) range from -22.2 to $-21.6 \%$ in the ZT core, from -26.4 to $-24.1 \%$ in the LA core, and from -27.2 to $-23.1 \%$ in the XFJ core, with average values of $-21.9,-25.4$, and $-24.9 \%$, respectively (Fig. 1). After the correction for the Suess effect, $\delta^{13} \mathrm{C}$ values $(\% \circ)$ vary from -21.7 to $-19.9 \%$ in the ZT core, from -25.1 to $-23.9 \%$ o in the LA core, and from -25.5 to $-22.9 \%$ in the XFJ core, with average values of $-20.8,-24.6$, and $-24.1 \%$, respectively (Fig. 1).

Elemental $\mathrm{C} / \mathrm{N}$ ratios vary from 3.51 to 9.34 in the ZT core, from 4.12 to 14.7 in the LA core, and from 2.3 to 10.1 in the XFJ core, with mean values of 5.56, 8.15, and 5.14, respectively (Fig. 1).
The detailed results from ${ }^{210} \mathrm{~Pb}$ and ${ }^{137} \mathrm{Cs}$ radiometric dating were reported previously (Duan et al., 2015). The mass accumulation rates (MARs) were cited and displayed in Table S1. As the ZT, LA, and XFJ reservoirs had been small lakes before the dam construction, the chronological records for the ZT, LA, and XFJ cores are longer than the timescales of the dam construction.

\subsection{Neutral sugar data}

The concentrations of seven monosaccharides (glucose, galactose, mannose, arabinose, rhamnose, fucose, and xylose) are presented in Figs. 2 and S2, and/or listed in Table S2. Glucose $\left(0.2-2.34 \mathrm{mgg}^{-1}\right)$ is the most abundant sugar in all the reservoir sediments, followed by galactose $\left(0.09-1.2 \mathrm{mgg}^{-1}\right)$, mannose $\left(0.03-0.92 \mathrm{mg} \mathrm{g}^{-1}\right)$, and xylose $\left(0.01-0.95 \mathrm{mg} \mathrm{g}^{-1}\right)$. Concentrations of arabinose $\left(0.05-0.77 \mathrm{mgg}^{-1}\right)$, rhamnose $\left(0.04-0.67 \mathrm{mg} \mathrm{g}^{-1}\right)$, and fucose $\left(0.02-0.43 \mathrm{mg} \mathrm{g}^{-1}\right)$ are relatively low in the reservoir sediments. The TCHO concentrations at the ZT, LA, and XFJ reservoirs range from 1.94 to $5.36 \mathrm{mgg}^{-1}$, from 0.51 to $6.4 \mathrm{mg} \mathrm{g}^{-1}$, and from 0.83 to $2.56 \mathrm{mg} \mathrm{g}^{-1}$, respectively, and show decreasing downcore trends in all the sediment cores. Carbohydrate yield (\%) is the molar concentration of monosaccharide carbon normalized by TOC. Carbohydrate yield (\%) ranges from 7.08 to $10.9 \%$ in the ZT core, from 2.31 to $13.53 \%$ in the LA core, and from 1.93 to $12.52 \%$ in the XFJ core, with average values of $8.68,7.79$, and $7.33 \%$, respectively (Fig. 3). 

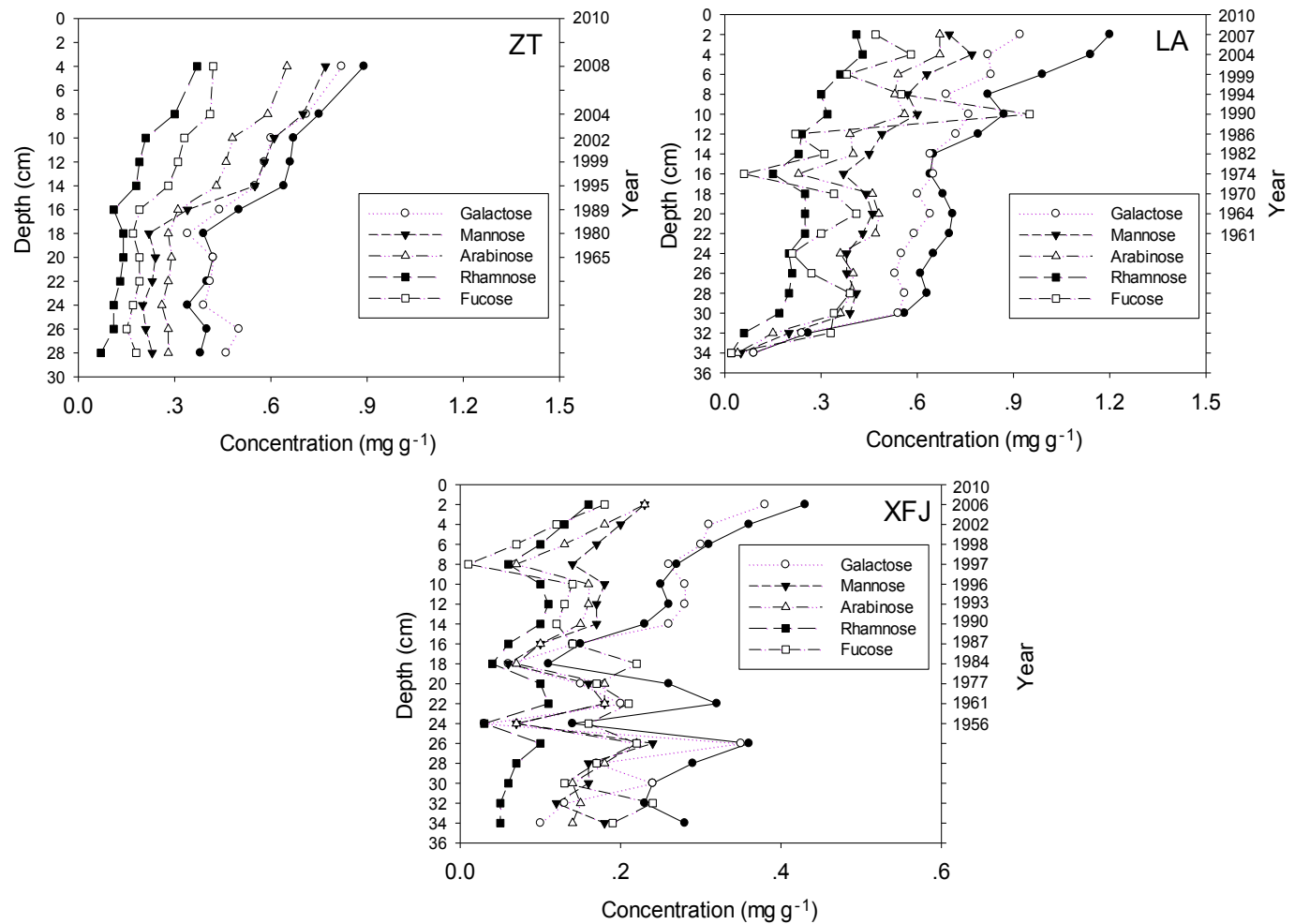

Figure 2. Profiles of neutral carbohydrates in sediment cores of the reservoirs.

Compositions of neutral sugars in the three sediment cores are calculated based on their concentrations. Glucose $(21.1-27.6 \mathrm{~mol} \%)$ is the most abundant monosaccharide, followed by mannose $(14-21.5 \mathrm{~mol} \%)$, galactose (14.7-18.7 $\mathrm{mol} \%)$, arabinose $(10.7-17.1 \mathrm{~mol} \%)$, rhamnose (11-12.9 mol\%), xylose (8.8-10.1 mol \%), and fucose (3.2$7.2 \mathrm{~mol} \%)$ in the ZT sediments. Glucose (22.2-37.4 mol \%) is also the most abundant monosaccharide, followed by galactose (12-20 mol\%), mannose (11.1-20.5 mol\%), arabinose (10.7-14.4 mol\%), rhamnose $(6.9-11.9 \mathrm{~mol} \%)$, xylose (5.09-18.32 mol \%), and fucose (3.3-7.74 mol \%) in the LA sediments. For the XFJ core, glucose $(18.5-48 \mathrm{~mol} \%)$ is still the most abundant monosaccharide, followed by galactose $(12.3-3.7 \mathrm{~mol} \%)$, mannose $(3.8-23 \mathrm{~mol} \%)$, arabinose (8.3-14.5 mol\%), rhamnose $(6-11.2 \mathrm{~mol} \%)$, xylose $(0.75-$ $21.6 \mathrm{~mol} \%)$, and fucose $(2.9-8.2 \mathrm{~mol} \%)$ in the sediment core.

\subsection{Meteorological records of the studied areas}

The 5-year moving average temperature $\left(T_{5}\right)$ was calculated from the reported database (Duan et al., 2015). The mean air temperature in the Guangzhou area has increased by about $1.5^{\circ} \mathrm{C}$ since 1960 , and the mean air temperature in the Heyuan area increased by about $1.52^{\circ} \mathrm{C}$ between 1957 and 2004. Therefore, the above data suggest a significant trend in climate warming in the investigated areas during the last
6 decades (Duan et al., 2015). The annual hours of daylight in Guangzhou and Heyuan on the timescale of 60 years have been obtained from the China Meteorological Data Sharing Service System (CMDSSS). The annual hours of daylight in both areas are somehow variable and show a progressively decreasing trend from 1950 to 2010 (Fig. S6).

\section{Discussion}

\subsection{OM characteristics in sediment cores}

The OM fractions derived from the Rock-Eval analysis could provide the source and early diagenetic information of $\mathrm{OM}$ in the reservoir cores. The S1, S2, S3, TOC, and HI show significant decreasing downcore trends in the ZT and LA cores, suggesting that the sedimentary OM has been affected either by autochthonous inputs or by extensive degradation (Duan et al., 2015). For the XFJ core, the TOC as well as the other pyrolytic parameters (except the HI proxy) show increasing trends with depth, suggesting that the degradation and oxidation of $\mathrm{OM}$ and/or terrestrial inputs of the $\mathrm{OM}$ are the primary factors affecting the variation of OM.

Carbon isotope analyses offer an important tool for identifying the sources of OM in lacustrine sediments. Different primary producers have distinctive carbon isotope compositions. The average $\delta^{13} \mathrm{C}$ values of $\mathrm{C} 3$ plants are around -27 to $-26 \%$, whereas the $\mathrm{C} 4$ plants have average $\delta^{13} \mathrm{C}$ values 

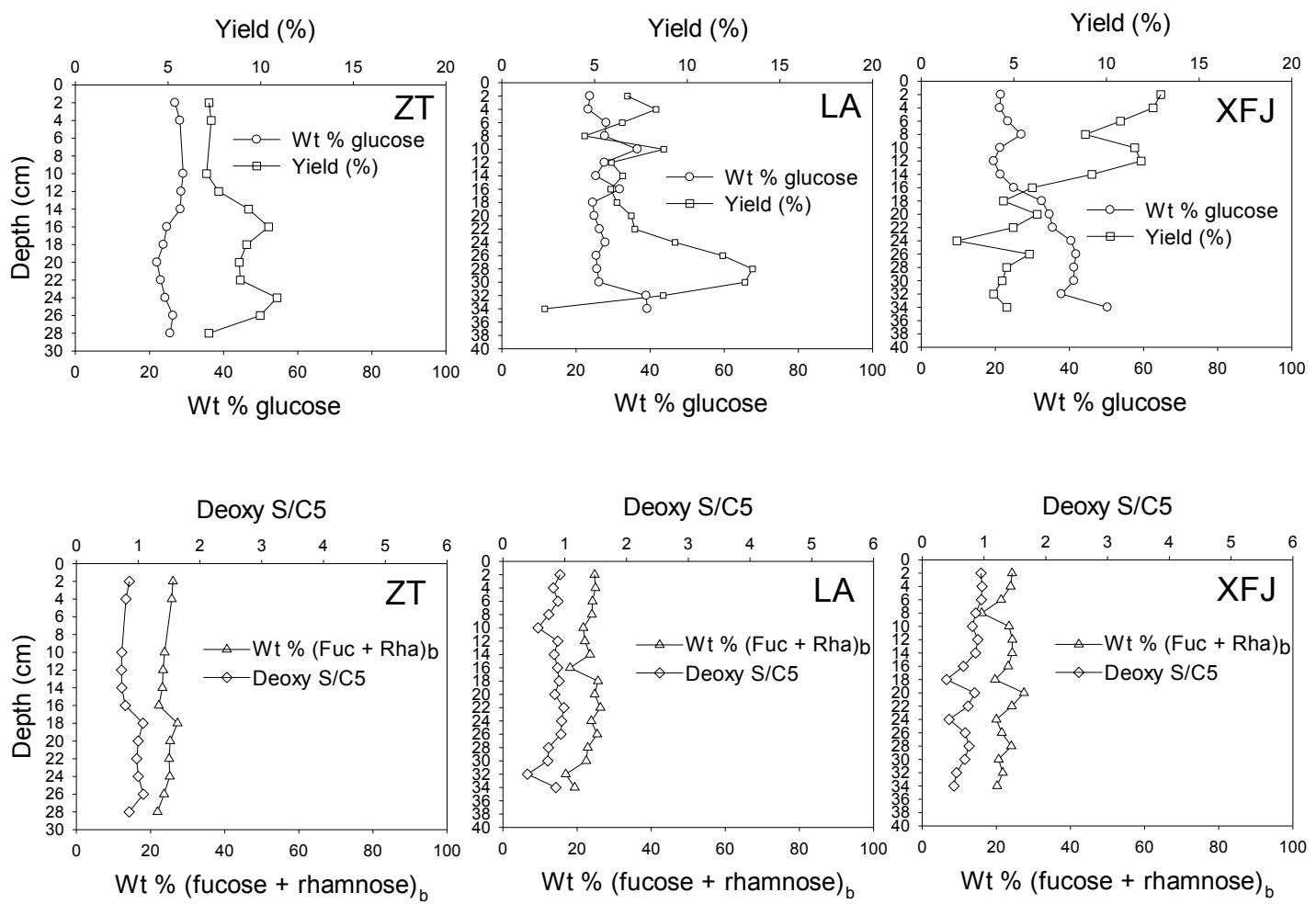

Figure 3. Vertical profiles of yield (\%), deoxy S / C5, wt \% glucose and wt \% (fucose + rhamnose) $)_{b}$ in the ZT, LA, and XFJ reservoirs.

of -14 to $-13 \%$. Although the $\delta^{13} \mathrm{C}$ values in phytoplankton are in a broad range of -17 to $-45 \%$ o (Boschker et al., 1995), phytoplankton can be identified by the combination of other proxies (e.g., elemental $\mathrm{C} / \mathrm{N}$ ratios). All the corrected $\delta^{13} \mathrm{C}$ values of sedimentary $\mathrm{OM}$ in the three reservoirs vary from -25.5 to $-19.9 \%$ (Fig. 1), which are in the range of phytoplankton and $\mathrm{C} 3$ plants. However, their corresponding $\mathrm{C} / \mathrm{N}$ ratios are relatively lower than those for higher plants (>12) (Fig. 1), suggesting the predominant contribution of phytoplankton in the OM of reservoirs. It is noted that the very low $\mathrm{C} / \mathrm{N}$ ratios in the XFJ core are likely to be related to inorganic $\mathrm{N}$ in minerals. As the TOC contents are quite low in XFJ, their inorganic $\mathrm{N}$ contents will affect the $\mathrm{C} / \mathrm{N}$ ratios. The $\delta^{13} \mathrm{C}$ values in ZT sediments are more enriched (average: $-20.8 \%$ ) than in LA (average: $-24.6 \%$ ) or XFJ (average: $-24.1 \%$ ) sediments, which may be attributed to high phytoplankton productivity (chlorophyll $a=90.7 \mu \mathrm{g} \mathrm{L}-1$ ), anaerobic sediments with high rates of methanogenesis, and lack of terrestrial carbon inputs in shallow water bodies. High phytoplankton can enhance isotopic fractionation and result in enrichment of ${ }^{13} \mathrm{C}$ in dissolved inorganic carbon. The removal of $\mathrm{CH}_{4}\left({ }^{13} \mathrm{C}\right.$ light) by intensive methanogenesis also leads to the accumulation of ${ }^{13} \mathrm{C}$-heavy $\mathrm{OM}$ in sediments ( $\mathrm{Gu}$ et al., 2004).

After correcting for the Suess effect, the OM in sediments becomes more enriched in ${ }^{13} \mathrm{C}$ from the bottom to the top of the ZT core (Fig. 1), reflecting a progressive increase in historical productivity, which is consistent with the vertical variations of TOC, C/N, and HI. Similar observations were also found in the LA core from a depth of $16 \mathrm{~cm}$ to the surface layer. Therefore, both the ZT and LA reservoirs undergo significant increases in primary productivity during the recent years. As shown in Fig. 1, the correction for the Suess effect can result in opposite conclusions regarding the aquatic productivity, based on uncorrected $\delta^{13} \mathrm{C}$ values for ZT and LA. Similar results were also observed in Lake Brunnsviken (Routh et al., 2004), Lake Eric (Schelske and Hodell, 1995), and the deep Lake Tahoe (Chandra et al., 2005), suggesting the importance, in terms of productivity, of the correction for the Suess effect in the recent $\delta^{13} \mathrm{C}$ values for lacustrine sediment cores.

For the XFJ reservoir, the corrected $\delta^{13} \mathrm{C}$ values increase from depths of 22 to $10 \mathrm{~cm}$ and then decrease abruptly to the surface layers, which may be related to the biodegradation of $\mathrm{OM}$ in aerobic sediments and/or a great amount of recent terrestrial loading. However, values of $\mathrm{C} / \mathrm{N}$ ratios in the upper layers of the $\mathrm{XFJ}$ core are very low $(\mathrm{C} / \mathrm{N} \approx 3)$ and indicate a contribution of algal origin in the sediments (Fig. 1). Therefore, the decrease in corrected $\delta^{13} \mathrm{C}$ at XFJ is mainly due to the biodegradation of $\mathrm{OM}$ under aerobic conditions. The preferential degradation of more ${ }^{13} \mathrm{C}$-enriched organic compounds (e.g., carbohydrates and proteins) would lead to a decrease in the $\delta^{13} \mathrm{C}$ values in the residue OM (Lehmann et al., 2002). 


\subsection{Monosaccharide compositions in sediment cores}

As shown in Table. S2, the TCHO concentrations in the ZT and LA cores show a significant decrease in the downcore sediments, which are similar to the vertical profiles of $\mathrm{S} 2$, TOC, C/N, corrected $\delta^{13} \mathrm{C}$, and HI (Tables S1 and S2). For the XFJ core, the TCHO and HI still decline in the downcore sediments, as do those in the ZT and LA cores (Tables S1 and $\mathrm{S} 2)$. In general, the contents of TCHO $\left(0.51-6.4 \mathrm{mg} \mathrm{g}^{-1}\right)$ in the three reservoirs are similar to those of a sediment core in the eutrophic French Aydat lake (1.19-4.58 $\mathrm{mg} \mathrm{g}^{-1}$ ) (Ogier et al., 2001), which was also enriched with neutral sugars at the surface layers of the sediment core.

Monosaccharide compositions were calculated for investigating the applicability of neutral sugars as productivity proxies. The compositions of neutral sugars in ZT and LA cores show that glucose is the most abundant sugar in these two reservoir sediments, while galactose, mannose, and arabinose are relatively more abundant than rhamnose, xylose, and fucose (Figs. 2 and S2), which is similar to the monosaccharide composition in phytoplankton (Hamilton and Hedges, 1988). Moreover, the relative abundances of monosaccharides do not vary much in the ZT and LA cores, except for the apparent changes in glucose and xylose at depths of 10, 16, 32, and $34 \mathrm{~cm}$ in the LA core. For the XFJ reservoir, the monosaccharide composition in the upper layers $(0-16 \mathrm{~cm})$ of the sediment core also indicates a dominant origin of algal carbohydrates. However, xylose significantly increases at a few depths (XFJ core: at 18, 24, and $32 \mathrm{~cm}$ depths) (Fig. 2). Furthermore, glucose shows an increasing trend and is correlated with the abundant xylose, especially between the depths of 18 and $34 \mathrm{~cm}$. The pattern of carbohydrate composition in these samples $(18-34 \mathrm{~cm})$ is not in agreement with the post-depositional process of diagenesis as observed in previous studies (Hamilton and Hedges, 1988; Hedges et al., 1994). They found that the diagenesis process often led to a decrease in glucose along with a corresponding increase in bacteria-derived deoxy sugars (rhamnose and fucose) in sediment cores. Therefore, these outliers $(18-34 \mathrm{~cm})$ might be related to increasing vascular plant input or hydrological variation at XFJ, as discussed in the following paragraph.

\subsection{Source of neutral carbohydrates}

Molecular-level diagnostic parameters have often been used to differentiate microbial, planktonic, and terrestrial sources (Cowie and Hedges, 1984; Guggenberger et al., 1994). They could be used as potential proxies for productivity in lakes and reservoirs. Diagnostic carbohydrate parameters and their results are presented in Figs. S3 and S4.

The ratios of mannose to xylose could indicate the OM sources derived from phytoplankton, bacteria, gymnosperm, and angiosperm tissues (Cowie and Hedges, 1984). As shown in Fig. S4, the values of the mannose / xylose ratios in most of the sediments at $\mathrm{ZT}$ and LA range from 1.51 to 2.70 and 1.49 to 3.50 , respectively, except at a depth of $8 \mathrm{~cm}$ (1.46) in the ZT core and at the depths of 4 (1.18), 8 (1.05), 10 (0.67), 16 (8.60), and 28-32 cm (0.6-1.33) in the LA core. Thus, most of the samples can be identified as a phytoplankton source (1.5-3.5), suggesting the important contribution of algal organic matter (AOM) in these two reservoirs. However, most of the mannose/xylose ratios are in the range of $0.23-0.87$ for gymnosperm tissues $(<1)$ at depths deeper than $16 \mathrm{~cm}$ in the XFJ sediments, which indicates the presence of terrestrial OM derived from angiosperm leaves and grasses.

The above conclusion is also confirmed by the $\%$ xylose parameters ("b" represents a value on a glucose-free base) plotted in Figs. 2 and S4. \%xylose $\mathrm{b}_{\mathrm{b}}$ is a useful biomarker to differentiate the type of terrestrial input (Cowie and Hedges, 1984). In most of the samples at ZT and LA, \%xylose $b$ is in the ranges of 9.34-11.8 and 7.10-15.8, respectively, except at the depths of 10 (23.5), 16 (3.02), and $32 \mathrm{~cm}(26.4)$ in the LA core. The low \%xylose $\mathrm{b}_{\mathrm{b}}$ values $(6.2-17.0)$ indicate the primary phytoplankton origin of neutral sugars at ZT and LA. The high values at the depths of 10 and $32 \mathrm{~cm}$ in the LA core might indicate important terrestrial input. Further evidence is also obtained from $\%$ (arabinose + galactose $)_{\mathrm{b}}$ plotted in Fig. S4 and from \% (fucose + rhamnose)b plotted in Fig. S3. The results from the $\%$ xylose $_{b}$ vs. $\%$ (fucose + rhamnose) $\mathrm{b}$ plots suggest a phytoplankton origin in reservoir sediments, which is consistent with that reported in the literature (Boschker et al., 1995). As for the \% (arabinose + galactose $)_{\mathrm{b}}$ ratios, their values are mostly in the range of 30.7-44.4 in the sediment cores at ZT, LA, and XFJ, indicating that the sedimentary OM samples are largely derived from phytoplankton with the ratios of 22-47. Only a few high values at a depth of $16 \mathrm{~cm}$ (48) in the LA core and at depths of $8 \mathrm{~cm} \mathrm{(50.6)} \mathrm{and} 34 \mathrm{~cm} \mathrm{(48.9)} \mathrm{in} \mathrm{the} \mathrm{XFJ} \mathrm{core} \mathrm{are} \mathrm{likely}$ to indicate an additional origin from non-woody angiosperm tissues and grasses, as demonstrated by Cowie and Hedges (1994). The above result also implies a different origin for neutral sugars in the upper layers of the XFJ core $(0-16 \mathrm{~cm})$ than in the lower layers $(>18 \mathrm{~cm})$, which have been increasingly affected by terrestrial input.

In order to support the above conclusions of the sources of OM derived from neutral sugars in the reservoirs, monosaccharide concentrations and heavy metal data are compared (Tables S3 and S4). It is found that almost all of the monosaccharides (except xylose at LA and XFJ) are significantly related to heavy metals (e.g., $\mathrm{Zn}$ and $\mathrm{Cu}$ ) in the sediment cores of ZT and LA, and the upper layers of the XFJ core $(0$ $16 \mathrm{~cm}$ ) (Table S4). However, only galactose, mannose, and fucose are positively correlated with $\mathrm{Zn}$ and $\mathrm{Cu}$ in the core of XFJ $(0-34 \mathrm{~cm})$, although the lower layers are increasingly affected by allochthonous input, as discussed in the above paragraphs. As $\mathrm{Zn}$ and $\mathrm{Cu}$ are essential nutrients for phytoplankton growth, these relationships provide additional evidence for the important contribution of AOM to carbohydrates in 
the investigated sediments. However, the $\mathrm{Pb}$ contents in the sediments of these reservoirs are very low, suggesting that there is no or little industry contamination in the investigated areas.

The ZT reservoir is a shallow reservoir and has a relatively higher trophic level. The LA reservoir is deeper and has a longer water residence time and a medium trophic level. Both the ZT and LA reservoirs are dominated by autochthonous green algae and diatoms, which contribute to the majority of carbohydrates in their sediments. However, the XFJ reservoir receives a relatively high input of higher plants from the surrounding runoff. Therefore, the different sources of carbohydrates are related not only to input of algae and plants, but also to historical changes in hydrological conditions and nutrient levels, etc.

\subsection{Diagenesis of neutral carbohydrates}

Carbohydrates are useful not only in identifying the sources of $\mathrm{OM}$, but also in evaluating early diagenetic processes occurring in the post-depositional environment. The four parameters, deoxysugar/pentose (deoxy S / C5) ratio, glucose content (mol \% or wt \%), \% (fucose + rhamnose) b, and carbohydrate yield $(\%)$ in the sediment cores are often used to evaluate diagenetic changes in OM (Cowie and Hedges, 1984; Ittekkot and Arain, 1986; Opsahl and Benner, 1999; Benner and Opsahl, 2001; Kaiser and Benner, 2009).

Glucose content is an important factor used to assess the degradation state of OM. Glucose accounts for 58 to $90 \%$ of the carbohydrates in fresh plankton and terrestrial tissues (Cowie and Hedges, 1984; Opsahl and Benner, 1999; da Cunha et al., 2002). Hernes et al. (1996) proposed that relative mol\% glucose in particulate OM could be used as a diagenetic indicator of organic material in the equatorial Pacific region. In this investigation, wt $\%$ glucose in the sediments ranges from 22 to $29.1 \%$ at ZT, from 23.3 to $39.2 \%$ at LA, and from 19.6 to $50.3 \%$ at XFJ (Fig. 3), suggesting that neutral sugars are biodegraded in the sedimentary OM. This conclusion is also confirmed by the carbohydrate yields (\%), which usually represent $30-40 \%$ of TOC in fresh tissues of plant and phytoplankton but less than $9 \%$ in sediments (Cowie and Hedges, 1984; Opsahl and Benner, 1999). Carbohydrate yields range from 1.93 to $13.53 \%$ in the sediments of the three reservoirs (Fig. 3). It is also suggested that neutral sugars degrade significantly in the investigated sediments. These results are consistent with the general observation from previous studies (Ogier et al., 2001). In general, the carbohydrates in the reservoir sediments are extensively transformed and degraded. However, the stability of their compositions was observed in the downcore sediments. Whether the carbohydrate compounds are degraded mainly in the water column or in the sediment core will be discussed below (Fig. 3).

Keil et al. (1998) found that the \% wt (fucose + rhamnose) $)_{b}$ values could reflect the diagenesis process of neutral car- bohydrates. This index was elevated as the sediment particle sizes decreased, suggesting that smaller size fractions showed a higher degree of degradation. Their observation was also consistent with other diagenetic indices such as lignin and non-protein biomarkers (Keil et al., 1998). In this study, the values of $\%$ wt (fucose + rhamnose) $b$ increase slightly, but the values of wt $\%$ glucose do not change significantly in each of the ZT, LA, and XFJ downcore sediments (Fig. 3), suggesting that the process of degradation occurs mainly during the settling period rather than after deposition. Further evidence in support of this conclusion can be obtained from the ratio of deoxy sugars (e.g., rhamnose and fucose) to C5 (e.g., arabinose and xylose) (deoxy S / C5). The deoxy S / C5 ratios increase slightly in the downcore sediments of ZT, LA, and XFJ (Fig. 3). Therefore, although sinking organic matter-rich particles and their carbohydrates suffer from intensive oxidation and degradation in the water column during their transit to bottom sediments, some fractions are selectively preserved in the sediment cores, and remained almost unchanged during post-deposition, as observed before (Cowie and Hedges, 1984; Moers et al., 1990; Hicks et al., 1994).

Carbohydrates consist of storage polymers and cell membranes of phytoplankton. In general, glucose is bound mainly in an unbranched, starchlike $\beta$-1,3-glucan storage polymer (Handa, 1969), whereas mannose, galactose, xylose, fucose, and rhamnose are characteristically more abundant in the cell walls (Cowie et al., 1992). In addition, a portion of carbohydrates is highly likely to be preserved by sedimentary clay minerals. Hence, the neutral carbohydrates in the sediment cores could be resistant to microbial degradation.

In support of the above conclusion, the $k$ values of deoxy $\mathrm{S} / \mathrm{C} 5$ were calculated using a "multi-G" model (Wang et al., $1998)$ to evaluate neutral sugar degradation. The $k$ value is $0.0025 \mathrm{yr}^{-1}$ for ZT, $0.0021 \mathrm{yr}^{-1}$ for LA, and $0.0025 \mathrm{yr}^{-1}$ for XFJ. Thus, the $k$ values of deoxy S / C5 indicate that the decomposition of $95 \%$ neutral sugar in reservoir sediments will take thousands of years, which is similar to the results of TCHO in the ocean sediments (Wang et al., 1998) and the degradation of OM in the lacustrine sediments ( $\mathrm{Li}$ et al., 2013).

As delineated above, the variations of $\mathrm{OM}$ and neutral sugars are related to trophic states, OM sources, and hydrological changes in different depositional environments. Moreover, the downcore OM profiles in some of the sediment cores investigated in other aquatic environments have not exhibited decreasing trends (Kirk et al., 2011; Meyers, 1997), which are not consistent with the traditional degradation model and mechanism. Hence, more works are needed for investigating sources, fractionations, and biodegradation products of carbohydrates in different aquatic environments. 

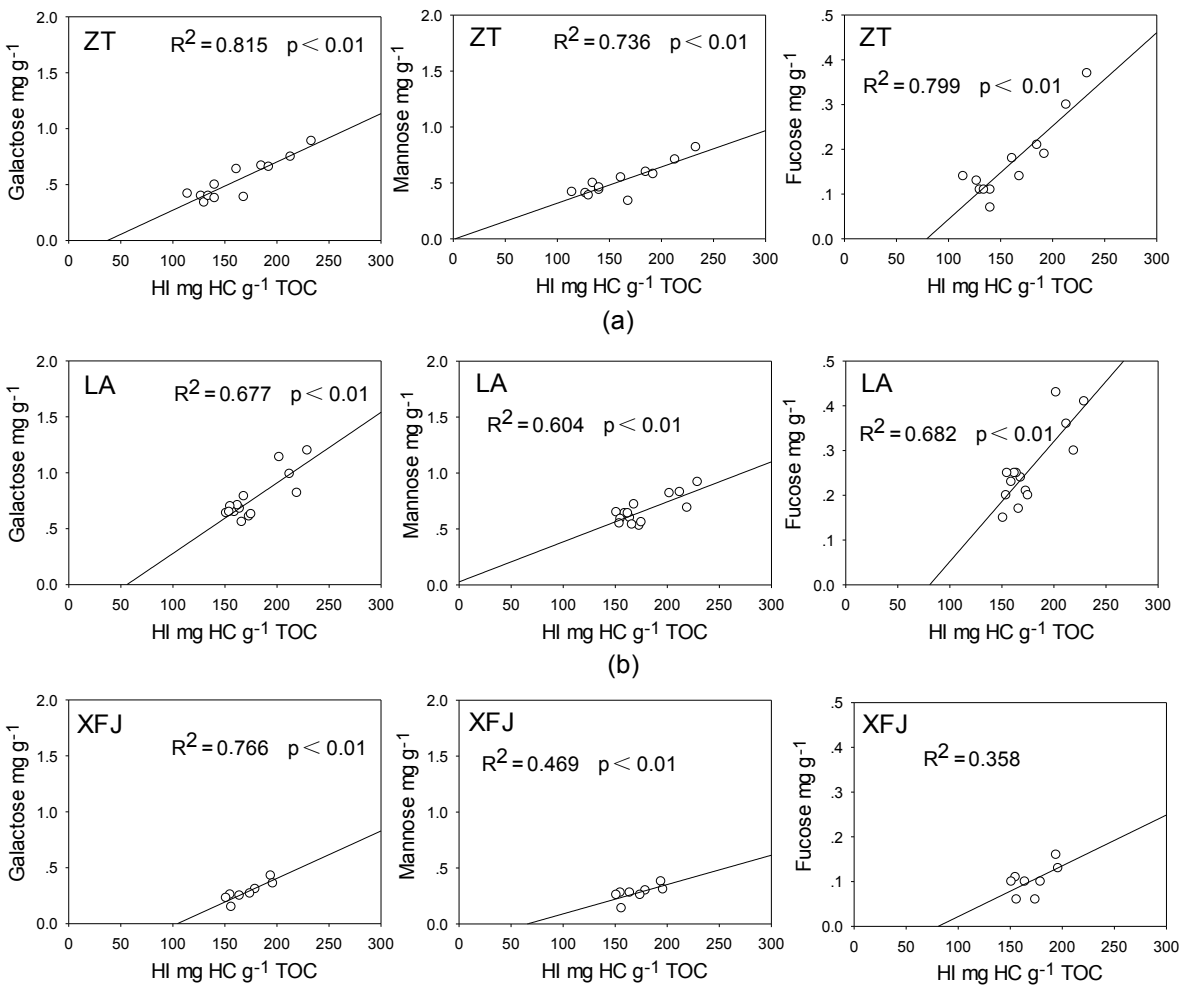

(c)

Figure 4. Relationship of HI with monosaccharide compounds in the ZT, LA, and XFJ reservoirs (for LA, the sample at 8-10 cm depths and at 30-34 cm depths were excluded; for XFJ, samples below $16 \mathrm{~cm}$ were excluded). The HI data are cited from Duan et al. (2015).

\subsection{Effects of climate change on primary productivity and carbohydrates}

As demonstrated above, a considerable amount of resistant structural carbohydrates could be preserved in the sediments. Moreover, $\mathrm{HI}$ has been widely utilized as a useful indicator of primary productivity during recent years (Gasse et al., 1991; Stein et al., 2006; Bechtel and Schubert, 2009). As shown in Fig. 4 and Table S4, the HI values in the ZT and LA cores are positively correlated with the concentrations of galactose, mannose, fucose, and arabinose, which are usually dominant in 89 cell walls of planktonic algae (Ittekkot and Arain, 1986; Hamilton and Hedges, 1988; D'souza et al., 2003; Hecky et al., 1973; Haug and Myklestad, 1976). For the XFJ core, significant correlations are also found between the concentrations of some monosaccharides and the HI values, except for rhamnose, fucose, and xylose. It is noted that a few samples at depths of 8-10 $\mathrm{cm}$ and $30-34 \mathrm{~cm}$ in the LA core and at depths of $18-34 \mathrm{~cm}$ in the XFJ core are excluded due to the inputs of allochthonous OM to the sediment cores. Therefore, monosaccharides (e.g., galactose and mannose) can be used for the reconstruction of historical productivity in the subtropical reservoirs.

As shown in Table S4, the contents of glucose, galactose, arabinose, mannose, fucose, and rhamnose are also positively correlated with S2 and HI values in the ZT, LA, and XFJ sediment cores. However, each of them shows weak correlations with the diagenetic parameters of neutral sugars such as \% (fucose + rhamnose) ${ }^{\mathrm{b}}$ and deoxy S / C5. Moreover, the xylose concentrations representing terrestrial inputs do not show significant correlations with the productivity proxies such as S2 and HI, and with any of the other monosaccharide concentrations at LA and XFJ. Thus, the above evidence supports the finding that the increasing neutral sugars in the reservoir sediments are mainly attributed to algal productivity rather than the degradation of neutral sugars during postdiagenesis.

In order to understand the effects of climate change on the historical variations of primary productivity, the $T_{5}$ values over 60 years are compared with each of the carbohydrate profiles in the three reservoirs (Fig. 5 and Table S4). The monosaccharide profiles at ZT and LA show a good correlation with $T_{5}$ during the past 60 years (for ZT, galactose: $T_{5}$, $R^{2}=0.824, p<0.01$; mannose: $T_{5}, R^{2}=0.824, p<0.01$; fucose: $T_{5}, R^{2}=0.805, p<0.01$; for LA, galactose: $T_{5}$, $R^{2}=0.885, p<0.01$; mannose: $T_{5}, R^{2}=0.699, p<0.01$; fucose: $T_{5}, R^{2}=0.883, p<0.01$;), suggesting that an increase in temperature enhances the deposition of carbohydrates in sediments (Fig. 5 and Table S4). Moreover, total nitrogen $(\mathrm{TN})$ and total phosphorus (TP) concentrations show 

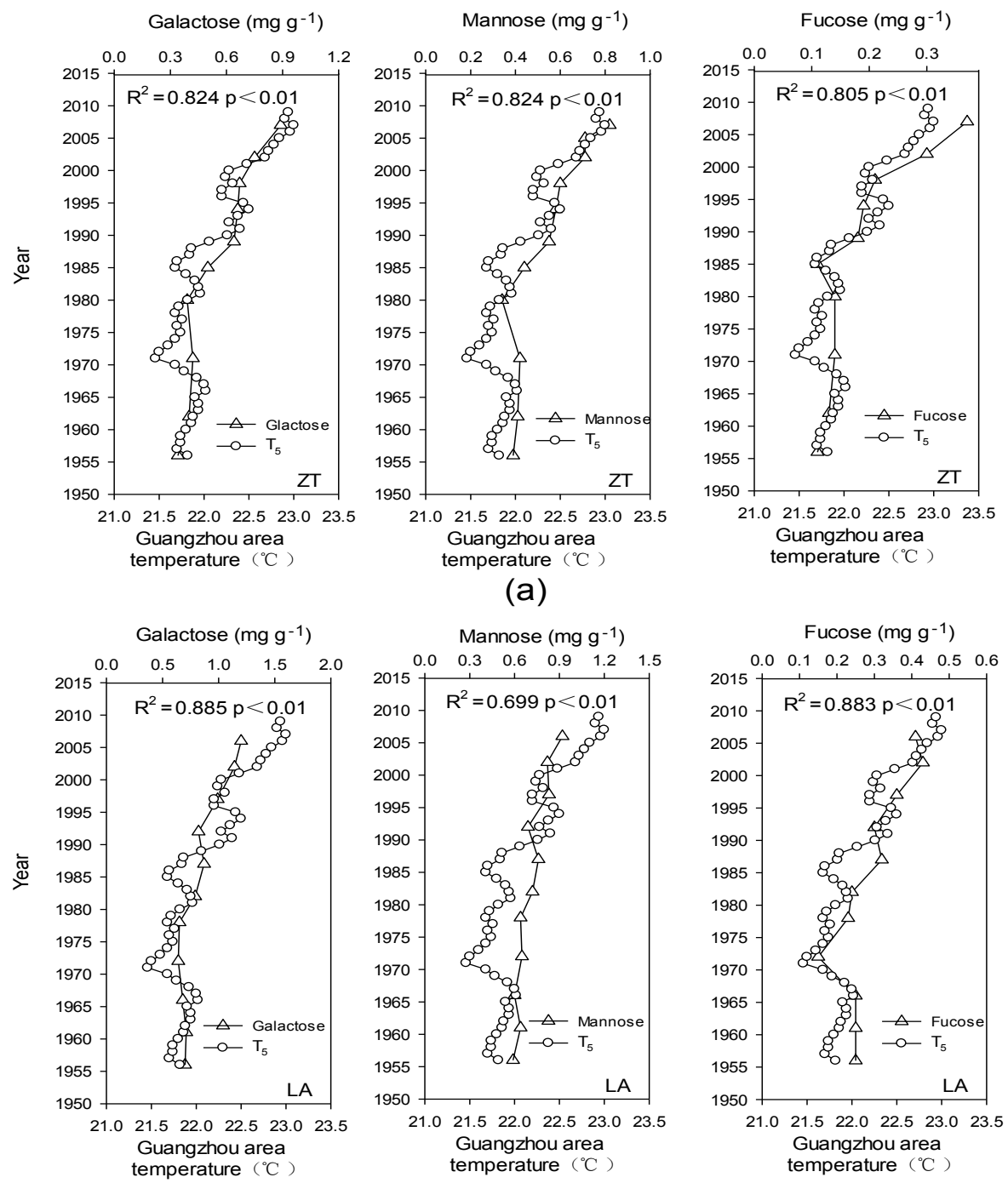

(b)
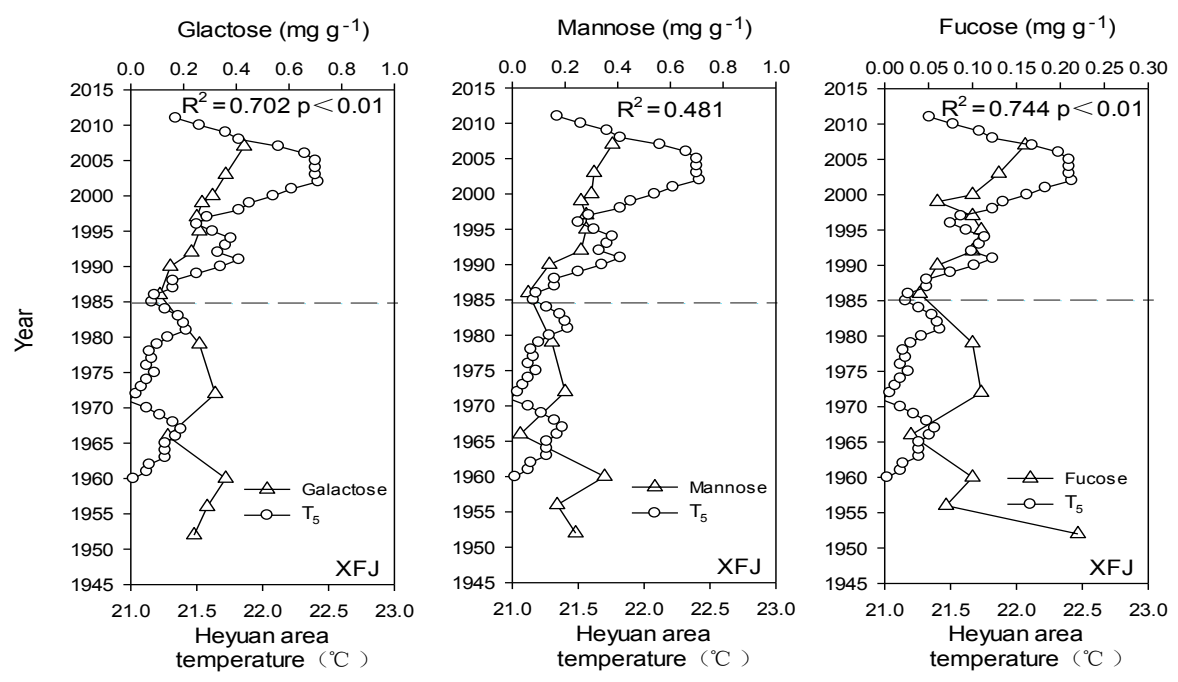

(c)

Figure 5. Temporal profiles of 5-year moving temperature $\left(T_{5}\right)$, hydrogen index $(\mathrm{HI})$ and monosaccharides in sediment cores from the three reservoirs. 
weaker correlations with $T_{5}$ than carbohydrates for the sediment cores of ZT and LA (Table S5; Duan et al., 2015). The TN and TP concentrations can be used to reflect the historical inputs of nutrients in the ZT and LA reservoirs. Furthermore, the TP and TN concentrations at $\mathrm{ZT}$ and LA remained at a low level (mostly $\mathrm{TP}<0.1 \mathrm{mgg}^{-1}, \mathrm{TN}<0.4 \%$ ) during the past 6 decades and are far lower than those in sediments of other eutrophic reservoirs (Duan et al., 2015). Further evidence can be found from principal component analyses (PCAs) in Fig. S5. The $T_{5}$, HI, and monosaccharides are in the first principal component and account for 76.5 and $67.3 \%$ of the total variance in the LA and XFJ reservoirs, whereas the second principal component of TP and TN accounts for 8.36 and $11.7 \%$ of the total variance, respectively. Hence, the nutrient input is not the key factor affecting carbohydrates in the three reservoirs. In addition, the factor of light can also be excluded by the records of the annual hours of daylight, which show progressively decreasing trends from 1950 to 2010 at Guangzhou and Heyuan (Fig. S6). In conclusion, the increase in carbohydrates in the sediments at ZT and LA correlates very well with the increase in temperature (Fig. 5). For the XFJ reservoir, the profiles of monosaccharides also show a positive correlation with the temperature variations (for XFJ, galactose: $T_{5}, R^{2}=0.702, p<0.01$; fucose: $T_{5}, R^{2}=0.744, p<0.01$;), but show no relationship with TN or TP concentrations (Fig. 5, Table S4). Although the primary productivity is lower in the XFJ reservoir than in the ZT or LA reservoirs, it is still significantly affected by the increasing temperature. Although the TOC and S2 values have declined with increasing temperature in the XFJ core profile due to the phosphorus-limited trophic level, the monosaccharide contents still increase (Fig. 5). Therefore, the above results suggest that some monosaccharides derived from algae cell walls in the ZT, LA, and XFJ reservoirs are strongly associated with climate warming in the subtropical area.

As shown in Table S4, positive correlations among corrected $\delta^{13} \mathrm{C}$ values, $\mathrm{HI}$, monosaccharide contents, and $T_{5}$ are significant in the ZT core. However, the corrected $\delta^{13} \mathrm{C}$ in the LA and XFJ cores are not correlated with other production parameters and $T_{5}$. This may be related to the impacts of organic matter degradation, terrestrial inputs, and human activities on the carbon isotopic composition $\left(\delta^{13} \mathrm{C}\right)$ in mesotrophic LA and oligotrophic XFJ reservoirs. Moreover, the HI values and monosaccharide data show the same changing trends, and each of them is positively correlated with five $T_{5}$ in each of the three reservoirs. Thus, the HI parameters and monosaccharide contents are more reliable for reconstructing historical productivity in subtropical reservoirs. Therefore, the combined uses of these parameters are strongly recommended, which can help us to better understand the historical change in productivity in the subtropical reservoirs. It is challenging to find the appropriate indicators of primary production in aquatic ecosystems. More works are needed to investigate specific fractions of organic matter as productivity proxies. Meanwhile, multiple biomarker proxies are also employed to trace the source of biological productivity, and to rule out the impact of human activities. Moreover, compound-specific isotope ratios and biodegradation products of biomarkers such as neutral sugars and lipids could provide more information on algal organic matter in aquatic ecosystems. Furthermore, the modeling of the relationships between air temperature and algal organic matter parameters is worth being exploited and established.

\section{Conclusions}

The source, composition, and diagenesis of carbohydrates in the three sediment cores were investigated by conducting acid hydrolysis coupling with high-performance liquid chromatography (HPLC) with pulsed amperometric detection (PAD). Glucose, mannose, and galactose are the most abundant monosaccharides. Monosaccharide composition and diagnostic parameters (mannose/xylose ratio, arabinose plus galactose, xylose) indicate a predominant contribution of phytoplankton in the whole sediment cores of the ZT and LA reservoirs and in the upper layers of the XFJ core (0$16 \mathrm{~cm}$ ). The carbohydrates are partially degraded during the settling. It was found that the degradation proxies (S2 / RC, $\%$ wt (fucose + rhamnose) $)_{b}$, and deoxy S / C5) did not vary much in each of the downcore sediments.

The corrected $\delta^{13} \mathrm{C}$ values can be used to reflect the historical changes in productivity. Elevated productivity derived from corrected $\delta^{13} \mathrm{C}$ values was observed in the upper layers of the ZT and LA reservoirs, which is consistent with the increasing monosaccharides (e.g., galactose, mannose, fucose, and arabinose) and $\mathrm{HI}$. But the corrected $\delta^{13} \mathrm{C}$ values abruptly decrease with very low $\mathrm{C} / \mathrm{N}$ ratios, which may indicate a different OM source and biodegradation in the downcore XFJ sediments. Moreover, strong positive correlations between some of the monosaccharides and $\mathrm{HI}$ were observed in both the mesotrophic ZT and LA reservoirs and in the oligotrophic XFJ reservoir, suggesting that the monosaccharides derived from algae cell walls and/or preserved in the mineral matrix are related to primary productivity in the studied subtropical reservoirs. Furthermore, increasing levels of carbohydrates in the three reservoir cores show significant relationships with $T_{5}$ during the last 60 years. Elevated temperatures lead to increasing levels of carbohydrates in the sediment profiles. Therefore, this investigation provides important evidence for the effect of climate change on the aquatic ecosystems in the low-latitude region. To further develop the productivity indicators of carbohydrates, more investigations are needed to understand their fractionation, biodegradation products, and compound-specific isotope ratios, and to improve their detection of other monosaccharides such as ribose. 
Data availability. Data supporting Figs. S1-S6 are available as Tables S1-S4. The annual average air temperature and 5-year moving averages of the air temperature on the timescale of 60 years in the Guangzhou area and Heyuan area were obtained from the China Meteorological Data Sharing Service System (CMDSSS).

\section{The Supplement related to this article is available online at https://doi.org/10.5194/bg-14-4009-2017-supplement.}

Author contributions. JC and YR designed the experiments and DD, DZ, JW, and YY carried them out. DD prepared the manuscript with contributions from all co-authors.

Competing interests. The authors declare that they have no conflict of interest.

Acknowledgements. This study was supported by a project of the National Natural Science Foundation of China (41473103), a key project of NNSFC-Guangdong (U1201235), and a project of the Earmarked Foundation of the State Key Laboratory (SKLOG2016A06). We thank Ronald Benner and Michael Philben at the University of South Carolina for help with the analysis of neutral sugars conducted in Benner's laboratory. This is contribution no. IS-2434 from GIGCAS.

Edited by: Gerhard Herndl

Reviewed by: three anonymous referees

\section{References}

Aufdenkampe, A. K., Mayorga, E., Hedges, J. I., Llerena, C., Quay, P. D., Gudeman, J., Krusche, A. V., and Richey, J. E.: Organic matter in the Peruvian headwaters of the Amazon: compositional evolution from the Andes to the lowland Amazon mainstem, Org. Geochem., 38, 337-364, 2007.

Bechtel, A. and Schubert, C. J.: A biogeochemical study of sediments from the eutrophic Lake Lugano and the oligotrophic Lake Brienz, Switzerland, Org. Geochem., 40, 1100-1114, 2009.

Benner, R. and Opsahl, S.: Molecular indicators of the sources and transformations of dissolved organic matter in the Mississippi river plume, Org. Geochem., 32, 597-611, 2001.

Boschker, H. T. S., Dekkers, E. M. J., Pel, R., and Cappenberg, T. E.: Sources of organic carbon in the littoral of Lake Gooimeer as indicated by stable carbon isotope and carbohydrate compositions, Biogeochemistry, 29, 89-105, 1995.

Burdige, D., Skoog, A., and Gardner, K.: Dissolved and particulate carbohydrates in contrasting marine sediments, Geochim. Cosmochim. Ac., 64, 1029-1041, 2000.

Carrie, J., Wang, F., Sanei, H., Macdonald, R. W., Outridge, P. M., and Stern, G. A.: Increasing contaminant burdens in an Arctic fish, Burbot (Lota lota), in a warming climate, Environ. Sci. Technol., 44, 316-322, 2010.
Chandra, S., Jake Vander Zanden, M., Heyvaert, A. C., Richards, B. C., Allen, B. C., and Goldman, C. R.: The effects of cultural eutrophication on the coupling between pelagic primary producers and benthic consumers, Limnol. Oceanogr., 50, 1368-1376, 2005.

Cowie, G. L. and Hedges, J. I.: Determination of neutral sugars in plankton, sediments, and wood by capillary gas chromatography of equilibrated isomeric mixtures, Anal. Chem., 56, 497-504, 1984.

Cowie, G. L. and Hedges, J. I.: Biochemical indicators of diagenetic alteration in natural organic matter mixtures, Nature, 369, 304 307, 1994.

Cowie, G. L., Hedges, J. I., and Calvert, S. E.: Sources and relative reactivities of amino acids, neutral sugars, and lignin in an intermittently anoxic marine environment, Geochim. Cosmochim. Ac., 56, 1963-1978, 1992

da Cunha, L. C., Serve, L., and Blazi, J. L.: Neutral sugars as biomarkers in the particulate organic matter of a French Mediterranean river, Org. Geochem., 33, 953-964, 2002.

D'souza, F., Garg, A., and Bhosle, N. B.: Biogeochemical characteristics of sedimenting particles in Dona Paula Bay, India, Estuar Coast. Shelf S., 58, 311-320, 2003.

Duan, D., Ran, Y., Cheng, H. F., Chen, J. A., and Wan, G. J.: Contamination trends of trace metals and coupling with algal productivity in sediment cores in Pearl River Delta, South China, Chemosphere, 103, 35-43, 2014.

Duan, D. D., Huang, Y. D., Cheng, H. F., and Ran, Y.: Relationship of polycyclic aromatic hydrocarbons with algae-derived organic matter in sediment cores from a subtropical region, J. Geophys. Res.-Biogeosci., 120, 2243-2255, 2015.

Gasse, F., Arnold, M., Fontes, J. C., Fort, M., Gibert, E., Huc, A., Li, B. Y., Li, Y. F., Liu, Q., Melieres, F., Van Campo, E., Wang, F. B., and Zhang, Q. S.: A 13,000-year climate record from western Tibet, Nature, 353, 742-745, 1991.

$\mathrm{Gu}$, B., Schelske, C. L., and Hodell, D. A.: Extreme ${ }^{13} \mathrm{C}$ enrichments in a shallow hypereutrophic lake: Implications for carbon cycling, Limnol. Oceanogr., 49, 1152-1159, 2004.

Guggenberger, G., Christensen, B. T., and Zech, W.: Land-use effects on the composition of organic matter in particle-size separates of soil: I. Lignin and carbohydrate signature, Eur. J. Soil Sci., 45, 449-458, 1994.

Hambright, K. D., Gophen, M., and Serruya, S.: Influence of LongTerm Climatic Changes on the Stratification of a Subtropical, Warm Monomictic Lake, Limnol. Oceanogr., 39, 1233-1242, 1994.

Hamilton, S. E. and Hedges, J. I.: The comparative geochemistries of lignins and carbohydrates in an anoxic fjord, Geochim. Cosmochim. Ac., 52, 129-142, 1988.

Handa, N.: Carbohydrate metabolism in the marine diatom skeletonema costatum, Mar. Biol., 4, 208-214, 1969.

Haug, A. and Myklestad, S.: Polysaccharides of marine diatoms with special reference to Chaetoceros species, Mar. Biol., 34, 217-222, 1976.

He, B., Dai, M., Huang, W., Liu, Q., Chen, H., and Xu, L.: Sources and accumulation of organic carbon in the Pearl River Estuary surface sediment as indicated by elemental, stable carbon isotopic, and carbohydrate compositions, Biogeosciences, 7, 33433362, https://doi.org/10.5194/bg-7-3343-2010, 2010. 
Hecky, R. E., Mopper, K., Kilham, P., and Degens, E. T.: The amino acid and sugar composition of diatom cell-walls, Mar. Biol., 19, 323-331, 1973.

Hedges, J. I., Cowie, G. L., Richey, J. E., Quay, P. D., Benner, R., Strom, M., and Forsberg, B. R.: Origins and processing of organic-matter in the Amazon River as indicated by carbohydrates and amino-acids, Limnol. Oceanogr., 39, 743-761, 1994.

Hernes, P. J., Hedges, J. I., Peterson, M. L., Wakeham, S. G., and Lee, C.: Neutral carbohydrate geochemistry of particulate material in the central equatorial Pacific, Deep-Sea Res. Pt. II, 43, 1181-1204, 1996.

Hicks, R. E., Owen, C. J., and Aas, P.: Deposition, resuspension, and decomposition of particulate organic matter in the sediments of Lake Itasca, Minnesota, USA, Hydrobiologia, 284, 79-91, 1994.

Ittekkot, V. and Arain, R.: Nature of particulate organic matter in the river Indus, Pakistan, Geochim. Cosmochim. Ac., 50, 16431653, 1986.

Jensen, M. M., Holmer, M., and Thamdrup, B.: Composition and diagenesis of neutral carbohydrates in sediments of the BalticNorth Sea transition, Geochim. Cosmochim. Ac., 69, 40854099, 2005.

Kaiser, K. and Benner, R.: Determination of amino sugars in environmental samples with high salt content by high-performance anion-exchange chromatography and pulsed amperometric detection, Anal. Chem., 72, 2566-2572, 2000.

Kaiser, K. and Benner, R.: Biochemical composition and size distribution of organic matter at the Pacific and Atlantic time-series stations, Mar. Chem., 113, 63-77, 2009.

Keeling, C. D.: The Suess effect: 13 carbon-14 carbon interrelations, Environ. Int., 2, 229-300, 1979.

Keil, R. G., Tsamakis, E., Giddings, J. C., and Hedges, J. I.: Biochemical distributions (amino acids, neutral sugars, and lignin phenols) among size-classes of modern marine sediments from the Washington coast region, Geochim. Cosmochim. Ac., 62, 1347-1364, 1998.

Khodse, V. B. and Bhosle, N. B.: Nature and sources of suspended particulate organic matter in a tropical estuary during the monsoon and pre-monsoon: insights from stable isotopes $\left(\delta^{13} \mathrm{C} \mathrm{POC}\right.$, $\delta^{15} \mathrm{~N}$ TPN) and carbohydrate signature compounds, Mar. Chem., 145, 16-28, 2012.

Khodse, V. B., Fernandes, L., Gopalkrishna, V., Bhosle, N. B., Fernandes, V., Matondkar, S., and Bhushan, R.: Distribution and seasonal variation of concentrations of particulate carbohydrates and uronic acids in the northern Indian Ocean, Mar. Chem., 103, 327-346, 2007.

Kirk, J. L., Muir, D. C., Antoniades, D., Douglas, M. S., Evans, M. S., Jackson, T. A., Kling, H., Lamoureux, S., Lim, D. S. S., Pienitz, R., Smol, J. P., Stewart, K., Wang, X. W., and Yang, F.: Climate change and mercury accumulation in Canadian high and subarctic lakes, Environ. Sci. Technol., 45, 964-970, 2011.

Lehmann, M. F., Bernasconi, S. M., Barbieri, A., and McKenzie, J. A.: Preservation of organic matter and alteration of its carbon and nitrogen isotope composition during simulated and in situ early sedimentary diagenesis, Geochim. Cosmochim. Ac., 66, 3573-3584, 2002.

Li, H., Minor, E. C., and Zigah, P. K.: Diagenetic changes in Lake Superior sediments as seen from FTIR and 2D correlation spectroscopy, Org. Geochem., 58, 125-136, 2013.
Meyers, P. A.: Organic geochemical proxies of paleoceanographic, paleolimnologic, and paleoclimatic processes, Org. Geochem., 27, 213-250, 1997.

Philben, M., Holmquist, J., MacDonald, G., Duan, D., Kaiser, K., and Benner, R.: Temperature, oxygen, and vegetation controls on decomposition in a James Bay peatland, Global Biogeochem. Cy., 29, 729-743, 2015.

Moers, M., Baas, M., De Leeuw, J., and Schenck, P.: Analysis of neutral monosaccharides in marine sediments from the equatorial eastern Atlantic, Org. Geochem., 15, 367-373, 1990.

Moers, M., Jones, D., Eakin, P., Fallick, A., Griffiths, H., and Larter, S.: Carbohydrate diagenesis in hypersaline environments: application of GC-IRMS to the stable isotope analysis of derivatized saccharides from surficial and buried sediments, Org. Geochem., 20, 927-933, 1993.

Ogier, S., Disnar, J. R., Albéric, P., and Bourdier, G.: Neutral carbohydrate geochemistry of particulate material (trap and core sediments) in an eutrophic lake (Aydat, France), Org. Geochem., 32, 151-162, 2001.

Opsahl, S. and Benner, R.: Characterization of carbohydrates during early diagenesis of five vascular plant tissues, Org. Geochem., 30, 83-94, 1999.

Outridge, P., Stern, G., Hamilton, P., Percival, J., McNeely, R., and Lockhart, W.: Trace metal profiles in the varved sediment of an Arctic lake, Geochim. Cosmochim. Ac., 69, 4881-4894, 2005.

Outridge, P., Sanei, H., Stern, G., Hamilton, P., and Goodarzi, F.: Evidence for control of mercury accumulation rates in Canadian High Arctic lake sediments by variations of aquatic primary productivity, Environ. Sci. Technol., 41, 5259-5265, 2007.

O'Reilly, C. M., Dettman, D. L., and Cohen, A. S.: Paleolimnological investigations of anthropogenic environmental change in Lake Tanganyika: VI. Geochemical indicators, J. Paleolimnol., 34, 85-91, 2005.

Panagiotopoulos, C., Sempéré, R., Para, J., Raimbault, P., Rabouille, C., and Charrière, B.: The composition and flux of particulate and dissolved carbohydrates from the Rhone River into the Mediterranean Sea, Biogeosciences, 9, 1827-1844, https://doi.org/10.5194/bg-9-1827-2012, 2012.

Parsons, T. R., Takahashi, M., and Hargrave, B.: Biological Oceanographic Processes, Pergamon Press, Oxford, New York, 1984.

Routh, J., Meyers, P. A., Gustafsson, O., Baskaran, M., Hallberg, R., and Schöldström, A.: Sedimentary geochemical record of human-induced environmental changes in the Lake Brunnsviken watershed, Sweden, Limnol. Oceanogr., 49, 1560-1569, 2004.

Schelske, C. L. and Hodell, D. A.: Recent changes in productivity and climate of Lake Ontario detected by isotopic analysis of sediments, Limnol. Oceanogr., 36, 961-975, 1991.

Schelske, C. L. and Hodell, D. A.: Using carbon isotopes of bulk sedimentary organic matter to reconstruct the history of nutrient loading and eutrophication in Lake Erie, Limnol. Oceanogr., 40, 918-929, 1995.

Skoog, A. and Benner, R.: Aldoses in various size fractions of marine organic matter: Implications for carbon cycling, Limnol Oceanogr., 42, 1803-1813, 1997.

Skoog, A., Alldredge, A., Passow, U., Dunne, J., and Murray, J.: Neutral aldoses as source indicators for marine snow, Mar. Chem., 108, 195-206, 2008.

Smol, J. P., Wolfe, A. P., Birks, H. J. B., Douglas, M. S., Jones, V. J., Korhola, A., Pienitz, R., Rühland, K., Sorvari, S., and Antoni- 
ades, D.: Climate-driven regime shifts in the biological communities of Arctic lakes, Proc. Natl. Acad. Sci. USA, 102, 43974402, 2005.

Stein, R., Boucsein, B., and Meyer, H.: Anoxia and high primary production in the Paleogene central Arctic Ocean: First detailed records from Lomonosov Ridge, Geophys. Res. Lett., 33, L18606, https://doi.org/10.1029/2006GL026776, 2006.

Stern, G., Sanei, H., Roach, P., Delaronde, J., and Outridge, P.: Historical interrelated variations of mercury and aquatic organic matter in lake sediment cores from a subarctic lake in Yukon, Canada: further evidence toward the algal-mercury scavenging hypothesis, Environ. Sci. Technol., 43, 7684-7690, 2009.

Unger, D., Ittekkot, V., Schäfer, P., and Tiemann, J.: Biogeochemistry of particulate organic matter from the Bay of Bengal as discernible from hydrolysable neutral carbohydrates and amino acids, Mar. Chem., 96, 155-184, 2005.
Verburg, P.: The need to correct for the Suess effect in the application of $\delta^{13} \mathrm{C}$ in sediment of autotrophic Lake Tanganyika, as a productivity proxy in the Anthropocene, J. Paleolimnol., 37, 591-602, 2007.

Wang, X. C., Druffel, E. R., Griffin, S., Lee, C., and Kashgarian, M.: Radiocarbon studies of organic compound classes in plankton and sediment of the northeastern Pacific Ocean, Geochim. Cosmochim. Ac., 62, 1365-1378, 1998. 